\title{
Violent Intermediaries and Political Order in Bangladesh
}

\author{
David Jackman ${ }^{1}$
}

Published online: 28 November 2018

(C) The Author(s) 2019

\begin{abstract}
The need for intermediaries to access resources, seek opportunities and mitigate risks has been observed in societies across the world. In poor people's lives such actors are often violent, however why this is the case remains under examined. This article offers a response to this question from Bangladesh based on an understanding of political order. When violence is not consolidated by a central state, political order stems from balancing the interests of diverse violence specialists dispersed throughout society. In such contexts mediating access to resources can be a means by which these actors accrue power and wealth, helping explain the link between intermediation and violence. This argument is developed through an ethnographic case of labourers in a large bazar at the centre of Dhaka city. The case illuminates the dynamics of political factionalism and violent mobilization within a fractious period in Bangladesh's recent history.
\end{abstract}

Keywords Violence $\cdot$ State $\cdot$ Intermediation $\cdot$ Brokerage $\cdot$ Labour $\cdot$ Politics . Bangladesh

Do you know what Bangladeshi politics is? It's capture, beat, cut, slash, rip, escape! Salam, a labourer at Karwan Bazar, Dhaka

David Jackman

dj8@soas.ac.uk

1 Department of Development Studies, School of Oriental and African Studies (SOAS), London, UK 


\section{Introduction}

The jupri (shack) group, as they are known locally, are a group of labourers who unload vegetables and live at Karwan Bazar, a large fresh goods wholesale market at the centre of Dhaka city. By day until late evening many members of the group rest adjacent to a government building, often splayed out on their flat backed rickshaw vans, awaiting the arrival of delivery trucks to unload, and the night of work ahead. The group come from all corners of Bangladesh, having been abandoned by their families or running away from home in childhood, and growing up together at the bazar. As children many were thieves, stealing and selling vegetables, partly living in NGO run shelters where friendships formed. Now older, in their late teens to thirties, together they are one of the main groups of labourers at the country's largest fruit and vegetable wholesale market. For some of them, the spot by the side of the bazar, which by day is sheltered from view by dilapidated buses, is also their home.

Visiting the bazar one day in late December 2014, I found the group had deserted their usual area, and I was leaving when I bumped into Abul, an older member of the group. Abul spoke to me in short whispers, looking over my shoulder and without explaining why, beckoned me to come with him. Weaving our way through the bazar he took me to a far flung corner I had not been to before, up a small staircase and to a lonely tea stall, where I found a couple of others in the group looking downcast, including one of the leaders, Rubel. Over the preceding weeks the jupri group had wrestled control of contracts for unloading carrots from a rival labour leader, however were now out of their depth. They had had to fight off a faction of the Chattro League (the student wing of the ruling political party, the Awami League) employed by the rival leader to reclaim control and were now facing multiple police cases, meaning key members of their group were ferari (fugitives) as they described it, and were being monitored by police informers. After discussing the group's situation over tea and a cigarette, Rubel asked me 'do you have anyone who could help us?' The senior local figure they knew would cost 'taka, taka, taka' to pay off the police, Abul explained, and they were also at a serious disadvantage, being aligned to the Bangladesh Nationalist Party (BNP), the political party in opposition. I was unable to help, I 'had' no-one I was clear, but wished them well. Before I left the group I heard them plan their next move, with Rubel instructing the group to get some monkey tuppee (balaclava) and attack the Chattro League that night.

The most striking feature of this vignette is not that the dynamics described are unusual or particularly extreme, but rather that they are commonplace. Though the setting here is a city market, the portrayal of violent struggles to control resources, the entanglement of police and party political actors in local affairs, and the search for relationships to mitigate the violence of others, can be heard from across Dhaka and wider Bangladesh (Devine 2002; Ruud 2014; Suykens 2015). It has been argued that in the Global South, rather than see 'citizens' and the state as having a direct relationship through democratic forms of accountability and governance, we should think of a 'state-intermediary-citizen' relationship, 
where people depend on varied types of intermediaries or brokers (these terms are used synonymously in this article) to access the state and market, and to represent their interests (Auyero 2001; Von Lieres and Piper 2014). In South Asia, the sense that intermediation is pervasive has led others to write of 'intermediation societies' (Wood 2010) or a 'mediated state' (Berenschot 2010). An important and yet neglected characteristic to such intermediation, which emerges clearly in the description of the jupri group above, is violence. Indeed in some contexts - although certainly not all - an ability to use violence is a key skill of intermediaries, and one which is essential to them maintaining and gaining status. The relationship between violence and intermediation has however been underappreciated empirically, and there has been little attempt to offer a theoretical account of why, in certain contexts, intermediaries are violent.

This article examines this question through the case of the jupri labourers, and proposes understanding violent intermediation in relation to political order. In many societies, including Bangladesh, it can be argued that political order rests not on the monopolisation of violence by a central state, but on a balance of power between diverse 'violence specialists' (North et al. 2009; Khan 2010). Such violence specialists vary widely in character, and can include gangs, mafia, political factions and the police; actors who operate in relationships of mutual support and collaboration, as well as competition (Arias 2017). In Bangladesh it is the state security forces as well as political factions within or aligned to the ruling Awami League party who are currently dominant, and are organised throughout society down to the grassroots. Political order in Bangladesh is premised on such actors maintaining power, for which accruing and distributing resources is critical. The proposition here is that intermediation can be an important means by which such violence specialists control and accumulate resources. When political order is contingent on the inclusion of diverse violence specialists, this may help explain why in certain contexts, intermediaries are often violent. The empirical narrative through which these arguments are both developed and explored contributes to an understanding of intermediation in Dhaka and Bangladesh, drawing particular attention to the role of labour leaders as pivotal to understanding the lowest levels of violence specialists, factionalism, and the organisation of political violence.

These arguments are built from an ethnography conducted in Dhaka between February 2014 and March 2015. Research centred on Karwan Bazar, which is situated at the heart of the city, adjacent to a five star hotel, the country's major media outlets, near a high end shopping centre and a bosti (slum) along the railway line which at the time was the city's largest open drugs market. The approach taken is political ethnography (Auyero 2001; Baiocchi and Connor 2008; Berenschot 2011), with an emphasis on access to resources and their negotiation (Ribot and Peluso 2003). Research focused on the lives of both children and adults living at the bazar, many of whom came to the bazar in childhood because of family abandonment or abuse. Most male labourers with such backgrounds work within the jupri group, who transport sacks of vegetables between rural middlemen (bepari) and urban wholesalers (aratdar, "commission agents") on the back of their flat backed rickshaw vans. The primary method deployed was participant observation with the group, working alone and spending long periods together before or during work, both by day and 
night. The intensity of this built incrementally as my relationship with the group developed, however I was forced to take a step back in early 2015 when key members of the group were arrested by the elite security force, the Rapid Action Batallion (RAB). Relationships were initially built through a nearby NGO with which I was informally associated. The names of the labour group and individuals have been anonymised.

\section{Violent Intermediaries and Political Order}

\section{Violent Intermediaries}

Liberal notions of citizenship, civil society and the state reflect a particular understanding of state-society relations, dominant characteristics of which are universal rights enshrined in laws and democratic forms of governance underpinned by a central state monopolising the means of violence. It is widely acknowledged that these characteristics remain distant ideals in the everyday lives of 'citizens' in most of the world, even where societies ostensibly embody such values (Chatterjee 2004). Attempts to understand state-society relations in the Global South have instead drawn attention to relationships of intermediation or brokerage, which have been identified as pervasive across the world (Auyero 2001; Bierschenk et al. 2002; Von Lieres and Piper 2014; Stokes et al. 2013; Tilly 2003; Wolf 1956). At its most basic brokerage can be understood as the 'production of a new connection between previously unconnected sites' (Tilly and Tarrow 2007, p. 31). Wolf (1956: 1076), for example, portrays brokers as actors who 'stand guard over the crucial junctures of synapses of relationships which connect the local system to the larger whole'. While research on brokerage has deep historical roots within the social sciences (Bierschenk et al. 2002), its re-emergence since the 1990s brought a particular interest in the dynamics of political brokerage, where political competition unfolds through brokers who facilitate relationships of exchange and mutual support (Auyero 2001; Gay 1998; Stokes et al. 2013). A common underlying argument is that different forms of intermediation exist to enable people to make claims on the state, access resources and the market; and that such actors are often critical to political competition.

In practice a vast array of resources, broadly defined, have been observed as mediated, including employment and labour markets, the ability to trade, housing, state services, justice and personal security. Similarly, a wide range of actors have been identified as brokers. Auyero's (2001, p. 58) analysis of the 'problem-solving networks that link "clients," brokers, and political patrons' at the grass roots in Buenos Aires, for example, highlights: 'NGO leaders, development agents, peasant association chairmen, association activists, facilitators, co-ordinators, politicians, clerks...' (Ibid: 20). The ways in which such actors broker access to resources are often not defined and regulated within the law, but operate 'informally', even if they are widespread and systematic. Studies have highlighted the complex and diverse 
roles brokers play, particularly in poor communities. Brokers can be charismatic figures (Hansen and Verkaaik 2009) who attend to desires for belonging and support (Auyero 2001). At the same time, the dependencies people have on these figures are often conceptualised through the language of patron-clientelism. ${ }^{1}$ As such they are seen as highly complex, and closely associated with the replication of poverty (Auyero 2001; Wood 2003). Auyero (2001, p. 70) argues that they reflect 'relations of clientelist domination', and Wood (2003, p. 455) conceptualises such relationships as 'Faustian bargains'. Simplistic distinctions between forms of brokerage, such as that between political 'clientelism' and 'civil society', break down under closer inspection, with for example NGOs in some cases operating through and reinforcing clientelist relations (Devine 2002).

A neglected dynamic to intermediation is its relationship to violence (Meehan and Plonski 2017; Wheeler 2014), and yet this relationship appears pervasive. As Tilly (2003, pp. 34-36) argues, political entrepreneurs throughout history are often both brokers as well as violence specialists. Diverse studies have witnessed to differing forms of 'violent entrepreneurs' (Blok 1974; Volkov 2002), actors who specialise in violence and mediate access to resources on that basis. While the most infamous case may be the protection racketeering of the Sicilian mafia, similar phenomena has been observed across the world. Cities in 1990s Russia saw what Volkov (2002, p. 1) described as 'the advance of bandits', gangsters specialising in protection racketeering. In literature from Latin America and the Caribbean the roles of gangs and gangsters have been highlighted as playing similar roles (Arias 2017; Johnson 2005; Rodgers 2006), such as the 'community dons' or 'garrisons' mediating between poor communities and the state in Jamaica (Johnson 2005). In South Asia, and particularly India, the figure of the goonda is often examined (Berenschot 2011; Michelutti 2007; Martin and Michelutti 2017). Berenschot (2011), for example, has examined how goonda are essential for party politicians to maintain local control, helping rig elections, raise money for political campaigns, and generally enforcing the politicians' control through violence.

This brief analysis suggests that across many societies violent intermediaries play important roles in people's lives, for example in mediating access to the market, state and wider society, although the terms by which these figures are identified clearly differ, as do the precise roles they play. This is not to exaggerate empirically and claim that all intermediaries are violent, or that the potential for violence is the sole or even primary characteristic constituting the power of intermediaries. As others have argued, and this study will also show, intermediaries draw from a complex array of qualities, which enable them to mediate across different contexts, and maintain their status (Auyero 2001). However these arguments do suggest, as Wheeler

\footnotetext{
1 Scott (1972) draws a distinction between a patron and a broker. For Scott the difference lies in whether or not the figure directly controls the resources they distribute. If they do, they are deemed a patron and involved in a 'two-person exchange' with a client, and if they do not, they are a broker and involved in a 'three party exchange' between two parties. In practice, as Scott acknowledges, people are often both. Indeed, empirically, many of the figures later discussed have strong dyadic relationships with their followers precisely because of their ability to mediate relationships to political or market actors, suggesting that it may not be helpful to draw a sharp analytical distinction between the two.
} 
(2014, p. 73) argues describing a favela in Rio de Janiero, that in many contexts 'violence shapes forms of mediation that inform how the state appears to citizens and how citizens see their citizenship and make claims on the state'.

\section{Dispersed Violence and Political Order}

Establishing a relationship between violence and intermediation draws attention to a more challenging question: why, in certain contexts, are intermediaries violent? The approach developed below offers a response to this question rooted in an understanding of political order, which builds closely from the concept of a 'Limited Access Order' (North et al. 2009) and work on 'political settlements' (Khan 2010). In many societies, the state as it is formally defined, does not hold a monopoly on violence, and political order-meaning the absence of widespread and large-scale violence-does not therefore originate with a central authority asserting its dominance and enforcing laws on this basis, as in the Weberian ideal. In such contexts the ability to use violence can be seen as 'dispersed' (North et al. 2009), meaning that a broad set of violence specialists, often with diverse organisational characters, use violence to promote their interests. Among others, this can include mafia, gangsters, political factions, trade unions, militia, and state security forces, actors who use violence 'entrepreneurially' (Blok 1974; Volkov 2002). In such societies political order requires cooperation and a balance of power between these differing violence specialists (Arias 2017; Goldstein and Arias 2010; Jackman 2018; Khan 2010; North et al. 2009). As Goldstein and Arias (2010, p. 20) argue similarly, political regimes 'coexist with organized, violent nonstate actors, and they stand side by side with multiple forms of substate order that exist separately from, but in constant interaction with, the state-sanctioned rule of law'. This argument resonates closely with studies, which have demonstrated the complex interdependencies between state and non-state violence specialists, and between national forms of governance and politics, and community level violence specialists (Arias 2017; Jackman 2018; LeBas 2013; Martin and Michelutti 2017; Volkov 2002).

One way of conceptualising the interdependencies between different violence specialists is through the notion of a 'ruling coalition' (North et al. 2009; Khan 2010). A ruling coalition is a complex inter-class network of actors, incorporating diverse elites and violence specialists both within and outside of the formal state, and organised as hierarchically linked factions, present throughout society down to the grassroots. Political order can be understood as requiring such a coalition to form, the coalition being incentivised to cooperate by maintaining mutual privileges, and by it excluding and dominating rivals (Ibid). In particular a 'double balance' is critical, where the capability one has for violence corresponds to economic power (North et al. 2009); and when 'enough of the potential organizers of violence are included within the ruling group' (Khan 2013, p. 34). Indeed, factions can vie for entry into 
or status within coalitions, and rival coalitions can form to threaten those in power. Khan $(2010,2013)$ offers a way of conceptualising different forms that a ruling coalition can take, arguing that while all coalitions require a degree of support from different hierarchical levels in society, they differ in terms of the factions included, and the balance of power between these. ${ }^{2}$ In practice, the relationships denoted by the term 'coalition', and the forms of governance this creates on the ground, are complex. As Arias' (2017) analysis of 'micro-level armed regimes' for example argues, the degree of consolidated power that non-state actors have differs, as do the levels of cooperation that they exhibit with the state.

For the ruling coalition, being in power brings opportunities and resources, which those outside of the coalition are denied. These benefits are diverse, including the 'manipulation of economic privileges' (North et al., 2009, p. 122)—for example the right to trade, control or have a monopoly over a market-as well as the ability to organise politically. Such resources are valuable for many reasons; critically because they are needed to incentivise members of a faction and coalition to mobilise or prevent rivals from challenging them (Khan 2010; North et al. 2009). To put it simply, a ruling coalition is not viable without resources to maintain it, and when the ruling coalition is not stable, political order breaks down. This suggests that the ways in which resources are accumulated and distributed by actors within the ruling coalition are essential for maintaining political order, raising the critical question of how this is achieved. The proposition here is that one important way in which violence specialists accrue resources is through relationships of intermediation. Controlling and mediating access to resources can itself provide resources, which violence specialists may seek as ends in themselves, but which are also instrumental to maintaining the viability of factions, and coalitions as a whole.

Empirically, this may mean that violence specialists themselves directly mediate the access that other people have to resources, or it could also mean that they somehow profit from the ways that others do so. Given that the violence specialists included within ruling coalitions can have diverse characters organisationally, and operate at different hierarchical levels within society, this suggests broad scope for the relationships this can denote. Examples may include extortion and protection racketeering, controlling employment opportunities, the ability to trade, housing, state services and personal security. Again, this is not to suggest that all forms of intermediation are necessarily controlled by violence specialists. However it does suggest that where violent intermediaries are observed, it may be instructive to analyse the roles they play and the dynamics such intermediation takes, through the model of political order outlined here, and therefore in relation to the concept of a ruling coalition.

\footnotetext{
${ }^{2}$ For Khan (2010) power within ruling coalitions differs vertically (according to the relative power of higher and lower level factions), and horizontally (according to the relative power of factions within and outside the coalition). Different types of political settlement emerge across these two variables. For example, where both lower level and excluded factions are strong, a 'competitive clientelist' arrangement emerges, characterised by a form of political competition, and regular transitions in power between ruling coalitions.
} 


\section{Politics, Labour and Violence in Dhaka City}

This section explores the framework developed above in Bangladesh through the case of the jupri labourers at Karwan Bazar in Dhaka. While it is acknowledged that generalisations cannot be drawn from a single case, the study suggests that violence is a key skill of intermediaries in this context, and that such intermediaries operate within or in opposition to the ruling coalition. The following sections develop these arguments empirically, particularly examining the roles of labour leaders, contextualising such intermediaries in relation to the ruling coalition in Bangladesh, and exploring two short cases of violent mobilisation.

\section{Coalitions, Parties and Factions in Bangladesh}

Following the return to parliamentary democracy in 1991, ruling coalitions in Bangladesh have been mobilised around the country's two premier political forces: the Awami League (AL) and Bangladesh Nationalist Party (BNP). Both parties are led by political dynasties, which hold widespread and comparable levels of public support (Khan 2010), and have a strong presence at the grassroots, organised through a myriad of different bodies and networks. In many respects the parties mirror each other organisationally, and can be seen as pyramids of hierarchically organised factions, linked through complex patron-client relations (Khan 2010; Suykens 2016). Both central parties are supported by wings or associated bodies representing particular interest groups, and these include students (chattro), youth (jubo), workers (sramik), volunteers (swechasebak) and farmers (krishok), identities that are generally associated with dal in the case of BNP or league in the case of the AL. These actors operate as violence specialists, which together with the security forces and politicised networks across society, are key actors within the ruling coalition.

Until recently power has oscillated between these parties regularly in a 'competitive clientelist' arrangement (Khan 2010). Power changed hands in 1991 (Ershad's military regime to BNP), 1996 (BNP to AL), 2001 (AL to BNP) and through 2006-2008 (BNP to AL). Once in power, the ruling coalition has access to extensive rent-seeking opportunities, leveraging control over the state and market to pursue these, while largely excluding rivals. This arrangement has historically enabled all actors who have a capability for violence to systematically access the resources that ruling brings (Khan 2010). Hence following the election of a new party, a transfer of power can be witnessed throughout society, from ministerial offices down to street level extortionists and even control over the halls of residence at public universities (Ruud 2014). In practice, each transition has been characterised by widespread and public violence as the coalitions vie to demonstrate their superior capability for violence and the legitimacy of their control over society. This typically involves mass strikes, street battles, bombings and arson, which are observed across the country, but centre on Dhaka, and are led by the groups described above. Holding this arrangement together has been a 'caretaker government' system, where elections are conducted under the supervision of a military backed government led by technocrats, preventing the incumbent coalition from utilising the apparatus of the state to 
suppress rivals (Khan 2010; Hassan and Nazneen 2017). By the time this research was conducted it was clear that this arrangement had broken down. In early 2014 the BNP boycotted the general election in response to the AL's decision to directly administer the elections, and this has been accompanied by what appears to be a massive consolidation of power by the AL. Indeed, the degree of control that the AL has over the state and society has led to descriptions of Bangladesh as a 'partyarchy' (Hassan and Nazneen 2017), or a 'party-state' (Suykens 2017).

Conflict in Bangladesh occurs not only between coalitions, but also within them. Coalitions are thus dynamic, as factions manoeuvre and compete for status and resources (Khan 2010). Such factionalism is commonplace, and referred to through Bengali terms such as daladali and grouping. To seek opportunities and prevent rivals from challenging one's authority within the ruling coalition, political factions thus need to show strength. This is demonstrated in different ways, for example by gathering people at political events to indicate popular support and manpower; by mobilising people violently in street protests, fights, killings and bombings (Andersen 2013; Ruud 2014); and by utilising the legal system to launch police cases and have opponents arrested. Such violence can be seen as a 'performative act' (Berenschot 2011, p. 269), designed to instill in others a sense of one's power, and therefore legitimacy to control resources, and play wider roles such as settling disputes or running extortion rackets. While political leaders stand above their followers hierarchically and can exercise control over them, they are also therefore dependent upon them, requiring their muscle and loyalty to maintain their status (Ruud 2014). The way this is achieved is complex, however providing resources and opportunities is crucial, necessitating political leaders to closely manage the territory and economy over which they can exercise authority. Further examining the organisation of this ruling coalition at the grassroots in Bangladesh helps illuminate the relationship between violence and intermediation.

\section{Interme diaries and the Jupri Labourers at Karwan Bazar}

Studies of bosti (slums) in Dhaka suggest that political leaders and those affiliated with them have comprehensive control over local resources such as housing, security, markets and utilities, control from which they accumulate wealth, and which is maintained through an underlying threat of violence (Banks 2016; Hackenbroch and Hossain 2012; Khan 2000; Suykens 2015). This and subsequent sections build on this work to examine such intermediation in the context of the jupri labourers at Karwan Bazar. With limited exception (Opel 2000) organised labour has been a neglected subject of research in urban Bangladesh, and to my knowledge this study represents the first analysis in Dhaka of the relations between labour groups and political parties.

For the jupri labourers gaining access to work, finding opportunities and remaining safe, are not guaranteed by the rule of law, or regulated according to market principles, but contingent on the relationships they maintain with senior and more powerful actors. Such dependencies provide an anchor to their lives, binding people together in complex ways. Being so important, they are the subject of much interest, 
and can be openly discussed and gossiped about, while at times are contentious and even hidden. For the jupri group, and indeed other labourers at the bazar, a key figure they rely upon for work, security and opportunities are labour leaders. Labour leaders are known as sardar, or hodar colloquially, and are a ubiqitious and powerful intermediary, who have received little academic attention in Bangladesh. At Karwan Bazar sardar control contracts for distributing goods between the bepari and aratdar, and typically organise the coolie (those carrying goods in baskets on their heads), the helper (those facilitating this, working by hand), and the rickshaw baan (van) drivers (those carrying goods on flat backed rickshaw vans). Sardar often have their name suffixed with the term, hence the name of the most proximate and powerful labour leader to the jupri group_Dulal sardar. Dulal is now elderly. He described to me having worked at Karwan Bazar for over forty years and having forty rickshaw van drivers under him. Sardar typically receive daily income from the vans that they own and rent to drivers (approximately 80-100 taka a day), along with a significant cut of the fee charged by the group to unload or reload the goods. People estimate that Dulal sardar earns about 1.5 lakh taka a month (one lakh is one hundred thousand).

The jupri group have a contentious relationship with Dulal, and although having previously worked under him, had in recent years managed to take control over their own contracts, which they managed through the group's boro bhai (big brother). These boro bhai play a similar structural role to sardar, although only managed the van drivers themselves, and were not referred to through this term. A younger van driver in the group described these boro bhai: 'Parvez bhai is top. Then Rubel. Then "mission" Azad'. These three boro bhai described being from the same 'batch' of boys who had grown up in NGO centres for street children. Like other labour leaders more generally, they play complex roles in the lives of the labourers under them. Relationships are spoken of in terms of whether they 'adore' each other, whether they care and love each other. Boro bhai are looked to for advice, support, guidance, and as well as providing work, they offer the security and respect that their names are accorded in the area. They also run savings groups (samiti), and this was a major source of income for Parvez, while Rubel earned a cut from managing the contracts that the group worked on, as well as renting out the six rickshaw vans he owned. The labourers often expressed that 'you have to have a boro bhai'.

Hierarchically above labour leaders in terms of status and power, are party political leaders and the security forces. At and around Karwan Bazar, as in other neighbourhoods of Dhaka, it is the party political actors described above who, along with the police, have a dominant capability for violence. As well as the central AL, a number of powerful affiliated bodies operate here including the Jubo League (youth wing), Sramik League (workers wing), Swechasebak League (volunteers wing) and Krishok League (farmers wing). The ward level leaders of these bodies are well known, referred to through the language of "leader", neta (leader) or more often and colloquially boro bhai. These actors themselves look up to senior political authorities such as MPs and Ministers, as well as the internal hierarchy of their particular body. A web of actors exist around these leaders, often termed cadre, which has connotations of a standing army or force. These cadre are sometimes derogatorily referred to as chamcha, meaning a 'yes man', someone who sucks up to a leader, 
always agreeing and praising him. A common form of cadre are "lineman" who collect the extortion or tolls (what is locally known as chanda or chaada) from street businesses and often also from labourers and their leaders. Operating under the police and paramilitary group the Rapid Action Batallion (RAB) are informers, known as former or "source" locally. At Karwan Bazar these figures can be labourers, beggars, or full time informers. Some run their own extortion networks on the basis of the power accorded to them, such as Shamim, who was a previous gangster turned former, while RAB's main former was a man called Sajid.

\section{Political Dependencies and Violence}

A critical way in which boro bhai and sardar mediate access to work, security and opportunities for labourers, is through positioning their group in relation to the police, informers, and local bodies of the ruling party described above. Political leaders and their cadre are publically respected, and at times feared by labourers and their leaders because of their capability for violence, which is associated both with manpower and the weapons they can wield, as well as their proximity to the police and the legal system which they can deploy to their own ends by virtue of being within the ruling party. The inequalities in power between labourers and political actors mean that labourers can be obliged to mobilise, even violently, in support of political leaders, and pay informal tolls or extortion. Every night at Karwan Bazar for example, cadre extract money from both labourers and their leaders when vegetables are delivered. As everyone knows, a refusal to adhere to these interests could easily lead to an individual or group losing an ability to work, facing the violence of political cadre or even a police case.

At the same time, labour groups can leverage their muscle to seek opportunities, mobilising either in support or opposition to the local political leaders in power. Although the Awami League bodies mentioned above are locally powerful, their leaders and direct cadre are a small group compared to the size of labour groups. Political leaders thus often require relationships with labourers to maintain their dominance locally (for example to control rivals, or demonstrate the support they hold locally to senior political leaders). As the jupri group often described it: political leaders have a need for labourers to demonstrate their strength. The nature of these ties differs. Some labour groups are employed on an event-by-event basis and are therefore flexible to operate with different political actors, while others are tied to a specific body of the Awami League through loyalty or formal registration and membership. Some groups of labour thus see these relationships as a means of accruing power, whether it is to gain territory (such as contracts for work) or a desire to control extortion networks, and often look up with jealousy at the wealth of political leaders and cadre. As the case of the jupri group below demonstrates, labour groups may also see an opposition leader as offering the best route to power, and thus labour groups can threaten the stability of actors within the ruling coalition.

The jupri group are renowned-so they often told me-as the best fighters at the bazar. I was safe because I was with them, and if they fight, then their enemies will run away to Bandarban (a remote hilly district in the South-East of 
Bangladesh), as one member put it. Collectively they brag about fighting, about how scared they made someone, about how strong they are as individuals or how notorious particular members are. Status in the group itself was contingent on being able to fight, invoke fear and be "daring" as it was put; and when discussing political opportunities and work, they would often generalise that 'you have to fight'. Among the three boro bhai, Rubel principally manages work, while Azad and Parvez specialise more particularly in violence. Rubel would refer to Azad as the "fireman" (said while indicating a pistol), and a 'very powerful man' (indicating stabbing motions) who served twelve years in Dhaka Central Jail for crimes committed during the reign of picchi Hannan, a gangster who previously controlled the bazar (Jackman 2018).

At the time of research, the jupri group were aligned with the opposition party, the BNP. These connections came primarily from Parvez and Azad who had affiliated the group with a local BNP leader prior to the 2014 general election, in anticipation that the party would contest and win the election (neither of which they did). Junior members of the group described having to trust these affiliations, not ask too many questions, and follow instructions from these boro bhai. In the period of political conflict preceding and during research, Parvez was paid around 30,000 taka per occasion to lead the jupri labourers into fights and skirmishes at the BNP leader's behest. But alongside this, the group's political affiliations were highly complex and they would also participate in Awami League events, as a labourer Liton explained:

Sometimes we do krishok [farmers], sometimes jubo [youth], sometimes chattro [student], whoever comes and gives us money. Sometimes we'll even do BNP. It's no problem, we can go to whichever meeting because we haven't signed with any. We haven't got registration with any.

On one of the occasions I witnessed, the Krishok League secretary from nearby Tejgaon arrived in his oversized suit and clipboard, and was greeted by cheers from the group. He immediately gave 100 taka to the group for tea, and then said he needed twenty people for a rally at a nearby area Farmgate. I resisted calls to come along, and the group left cheering the name of a local politician. Although the group would often explain their attendance in economic terms-they give us 200 taka to go, we can fill our stomachs, why wouldn't we go?! as one of the group put it—alongside this sat more complicated reasons, as Rubel explained:

Those who are involved with the BNP, they go to the Awami meetings if they are invited. It's like a tangle, it's complex for us. If today I am with Awami and I invite you to go to a meeting and you refuse, then I will inform the police and they will come to catch you. That's why we go. We have to go to save ourselves.

A key role of labour leaders such as the jupri boro bhai is then to navigate these relationships with political leaders, seeking security and opportunities, while also mitigating risks. Such dependencies are in practice complex. Public mobilisation for one party may for example conceal loyalty to another. Although the jupri 
group needed to demonstrate support for the Awami League, their capability for violence also gave them a degree of protection from these actors. Other groups of labourers had to pay local lineman chanda when unloading vegetables (often 5 taka per sack) while the jupri group were exempt. The fact that labour groups are relied upon by political leaders suggests we can see such groups as one of the lowest levels of violence specialists within and outside the ruling coalition.

\section{Taking Territory}

Operating as a labour leader like Dulal sardar or the jupri boro bhai represents a privileged economic and political position. It signifies an ability to control work, profit from a value chain, and also pursue a political agenda. As such, it is a coveted status. Leaders however differ in the reach of their economic control, and groups are in competition for more work. Key to the levels of control a group has is their capability for violence. This capability is not however simply defined by an ability for brute violence, but critically by one's status in relation to the ruling coalition. Groups more closely aligned to this coalition can draw upon the strength of actors within that coalition, who themselves can publically mobilise on the streets and utilise the powers of the state, giving a significant disadvantage to those aligned to the opposition. Events at the end of 2014 illustrate these points in the lives of the jupri labourers.

The 15th of December 2014 represented a break in the jupri group's usual routine of sleep, chatting and cigarettes in the early evening. By around $9 \mathrm{pm}$ the group had amassed around seventy of their members and blockaded a main entrance to the bazar. Their primary grievance was Dulal sardar, with whom tension had been rising the preceding month. They often called Dulal and other sardar "cheater" and thieves, and looked enviously at his control of contracts, while also describing him trying to take chanda from them, thereby taking a cut of their earnings. Having blocked the main entrance to their side of the bazar, the group demanded that the market authorities got rid of Dulal sardar, knowing that these authorities would not fight them off themselves and expressing: 'if we don't get the work, no-one will!' and 'it is either us or the sardar!'

The strike was ostensibly successful, and over the following days a series of negotiations took place, including with the Tejgaon central Awami League leader, and reportedly even the local MP. From this an agreement emerged that Dulal could keep the ownership of his 12 vans but the jupri group would take over his contracts. Dulal sardar became simply Dulal, and could not return to the bazar for fear of being beaten. Tension however remained, and less than a week later it became apparent that Dulal, the elderly and experienced sardar of decades, was not to be stopped so easily. In the evening of the 21 st of December Dulal sardar hired a faction of the Chattro League to fight off the jupri group. Salam, a jupri labourer, later described the event:

We completely beat them up. Dulal sardar paid students from the universities and colleges, they came at us at around $9 \mathrm{pm}$ in front of the bank. It lasted for two hours. When one of them hit Parvez that's when we all went crazy and 
fucked them up. Azad brought his guys and smashed a hook into one guy's head. He's a chamcha. He's in Dhaka Medical and will take six months to recover. They were taught the lesson of their lifetime

Despite winning the fight, jupri were defeated when the Chattro League called in the police, forcing the group to flee. The group scattered and the Chattro League subsequently took control of the jupri lane, posting men in the area to make sure they did not return. Rubel described the situation

After we took the work Dulal offered us 3.5 lakh to give it back, but we didn't agree. He acted over us, spread a rumour and arranged the fighting. Because we didn't take their money, they brought the "killer". They had 70 people. They brought the boys from Chattro League and paid them 2 lakh to fight, though they offered us 3.5 lakh. Our mistake was that we didn't accept the money.

The jupri group's BNP association was fundamental to their defeat. The rumour referenced above was that they supported the BNP, and indeed Azad had drawn on other BNP muscle in the fight, had been arrested and remained in prison during the rest of the research. Others were released but remained fugitives, as Rubel explained, 'because they did BNP and their party doesn't have any power now'. Meanwhile Dulal managed to maintain his regained status through payments to the AL for protection, but was too cautious to return to the bazar. Rubel and the jupri retained their contracts, and Parvez continued running his samiti, though only turned up infrequently at the bazar. Through the conflict, a faction within the group began to distance itself from the leadership, and Rubel began to publically soften his portrayal of their affiliation, expressing 'we aren't BNP, we aren't Awami, we are workers', and 'I'm both BNP and Awami. I do both, it depends on the situation'. But beneath the surface the group remained covertly loyal to the BNP, a decision that would make life even more precarious for Rubel and Parvez.

\section{Bombings and Arson: Threatening the Ruling Coalition}

Labour leaders not only seek opportunities for themselves and their group through competing locally for more control over work, but also directly seek status within the ruling coalition. Demonstrating a commitment to one of the major political parties, particularly when they are not in power, is a strong basis for future claims of increased access to work, formal status within local bodies of the party, or informal sources of income such as extortion rackets. For political leaders, labourers such as the jupri group are a source of relatively cheap muscle - they are poor, familiar with violence having grown up on the streets, and eager for opportunities. As such, they are particularly relied upon for more extreme acts of violence. As events in early 2015 however showed, such mobilisation may promise greater rewards, but comes with high levels of risk to those involved.

During the period described here, Bangladesh was highly unsettled politically. Khaleda Zia, the leader of the BNP, was put under effective house arrest (though in her office) and her party's attempts to organise blockades (abarodh) 
and strikes (hartal) had very limited success. A few years previously calling a hartal had meant a serious threat of mass violence, but by this period the ability of the opposition to mobilise activists on the streets was widely recognised as diminished, as it continues to be as of mid-2018. As a result, the opposition appeared to resort to more desperate and extreme measures to demonstrate their capability for violence and publically question the ability of the AL to maintain order. Between January 5th and February 24th there were approximately 119 deaths due to political violence in the country (Bergman 2015), including ruling party and opposition activists, as well as many civilians targeted in molatov cocktail blasts in public spaces and petrol bombs on buses.

At Karwan Bazar it was the jupri group who coordinated bombings and arson on behalf of the BNP during this period. These targeted buses, police and the underpass beneath Kazi Nazrul Islam Avenue. On at least one occasion they made national news (The Daily Star 2015). The report describes 'miscreants' throwing 'at least two crude bombs' at a bus in the north of the bazar, hurting the driver. Rather than implement these themselves, Rubel and Parvez used younger children who were scavengers and thieves also living at the bazar, some of whom had older siblings working in the group. Such use of street children in political violence is common in Dhaka (Atkinson-Sheppard 2015). For the boro bhai in the jupri group, this mobilisation was an investment, a way of signalling the strength of their faction and make a claim on their future role in the bazar were the BNP to get into power. It turned out to be a serious miscalculation. Around the $10^{\text {th }}$ of February Parvez was-so the jupri group allege-suddenly taken by RAB. Members of the group who saw the incident described the informer Sajid walking along with RAB who were dressed in white clothes (civil clothes). Pointing out Parvez, they allegedly grabbed him, and took him to near a government office where they tied him to another rickshaw van and beat him publically, targeting his hands and feet, before arresting him. Almost 2 weeks later, $\mathrm{RAB}$ had reportedly returned around 7:30 pm taking Rubel, and when I finished my research he was still in Dhaka Central Jail. A number of children associated with the group had also been arrested and charged with vandalising cars under BNP instruction.

Some of the group suspected that Parvez had been beaten and given information and that RAB had a long list of people they would take one by one. A number of the group reflected that Rubel would get out, but would have to pay huge amounts of money. 'Maybe when he gets out Rubel will kill the former', one reflected. By the end of February Parvez had been released on bail, having paid 50,000 taka, his hands and feet were fractured, and though he could walk, he could not work. His samiti had broken up and he therefore no longer received the daily income from this. He had however found new employment, which gives insight into how the ruling coalition co-opts those with a capability for violence: he had become a RAB informer. Liton described how they had beaten him and persuaded him with money, and 'he's really proud. He thinks he's a big person again, saying that he's now with RAB. He still has the BNP links, but they are quiet now'. 


\section{Conclusion}

This article began by suggesting that in many societies there is a relationship between intermediation and violence (Arias 2017; Berenschot 2011; Blok 1974; Volkov 2002; Wheeler 2014), and this was further evidenced by the case of the jupri labourers in Dhaka. The question then posed was why, in these contexts, such intermediaries are violent. The response to this question developed is rooted in an understanding of political order. When political order in a society rests not on a central state, which has consolidated the means of violence but rather on a balance of power between diverse violence specialists (North et al. 2009), it was argued that intermediation can be a means by which these actors accrue resources. Such resources were suggested to be important not only in their own right, but also instrumentally, in enabling violence specialists to maintain their factions, and for a ruling coalition to be sustained as a whole. Put simply: political order requires the dominance of a ruling coalition, a ruling coalition requires resources, and intermediation represents a means by which resources can be accrued.

The case of the jupri group supports this argument not only be showing the importance of violence to certain intermediaries, but by demonstrating that the ability of intermediaries to use violence is closely connected to their status in relation to the ruling coalition. Labourers are looked to as a source of muscle and finance for political leaders both within and outside the ruling coalition who need to maintain and demonstrate their own capability for violence, while labour leaders utilise this skill to seek opportunities and mitigate the risks that such dependencies pose. The failure of the jupri group to navigate this successfully and the ensuing beatings and arrests allegedly at the hands of the state illustrate the gravity of the choices made. They furthermore illuminate in microcosm Bangladesh's recent political transition away from competitive clientelism and towards the continued dominance of the current ruling party, highlighting how the security forces and their informers target, control and co-opt opposition party activists.

These arguments have a number of analytical implications for our understanding of violent intermediaries. First, because economic mediation can be a power base for actors within or outside the ruling coalition, this suggests we should see economic and political mediation as closely interlinked. Second, while we can draw attention to particular individuals - such as the boro bhai in the jupri group - the authority of such figures in this context is constituted not only by their individual qualities, but crucially, but their relationship to a group of followers on whom they can depend, and who they can motivate to mobilise. There is therefore strong reason to understand intermediaries in relation to factions. Third, these arguments suggest that intermediation should be seen as a locus of local political struggles - it is a source of resources, instrumental to political mobilisation, and therefore a coveted status. Fourth, the capability for violence of intermediaries should be seen as complex, and far more than brute force. It incorporates an ability to draw on more sophisticated tools such as police cases and imprisonment, all of which may only need to be threatened in order to be felt. Finally, violence 
should be seen as one among other skills that such intermediaries possess. As described at Karwan bazar, labour leaders have a number of qualities including being caring and having a moral authority, raising complex questions about how these interact and are co-constituted.

The relevance of these arguments to other contexts beyond Karwan Bazar, Dhaka and Bangladesh remains an open question, and as made clear, generalisations clearly cannot be drawn from a single case. It is likely that the relationship between a ruling coalition, intermediation and violence will vary in a number of ways: the violence specialists dominant in any society may differ (Jackman 2018), as will their relative power one to another (Arias 2017), and likely also the extent to which intermediation serves as a source of resources. In different contexts violence may be far less important a skill for intermediaries, raising the broader question of why such actors exist in specific contexts. It is hoped that the arguments and case developed here offer avenues for further research on violent intermediaries both in Bangladesh and beyond.

Acknowledgements This work was supported by the Economic and Social Research Council (Grant Numbers ES/J50015X/1 and ES/P500653/1). I would like to thank Joe Devine, Geof Wood, Mathilde Maitrot and Sam Hickey for reviewing earlier drafts of this article, as well as the guidance of anonymous reviewers.

\section{Compliance with Ethical Standards}

Conflict of interests The author confirms that there is no conflict of interest

Open Access This article is distributed under the terms of the Creative Commons Attribution 4.0 International License (http://creativecommons.org/licenses/by/4.0/), which permits unrestricted use, distribution, and reproduction in any medium, provided you give appropriate credit to the original author(s) and the source, provide a link to the Creative Commons license, and indicate if changes were made.

\section{References}

Andersen, M.K. 2013. The Politics of Politics: Youth Mobilization, Aspirations and the Threat of Violence at Dhaka University. PhD Thesis, Roskilde University, Roskilde, Denmark.

Arias, E.D. 2017. Criminal Enterprises and Governance in Latin America and the Caribbean. New York: Cambridge University Press.

Atkinson-Sheppard, S. 2015. The Gangs of Bangladesh: Exploring Organized Crime, Street Gangs and 'Illicit Child Labourers' in Dhaka. Criminology \& Criminal Justice 16 (2): 1-17.

Auyero, J. 2001. Poor People's Politics: Peronist Survival Networks and the Legacy of Evita. Durham: Duke University Press.

Baiocchi, G., and B.T. Connor. 2008. The Ethos in the Polis: Political Ethnography as a Mode of Inquiry. Sociology Compass 2 (1): 139-155.

Berenschot, W. 2010. Rioting as Maintaining Relations: Hindu-Muslim Violence and Political Mediation in Gujarat, India. Civil Wars 11 (4): 414-433.

Berenschot, W. 2011. Everyday Mediation: The Politics of Public Service Delivery in Gujarat, India. Development and Change 41 (5): 883-905.

Bergman, D. 2015. Political Crisis of 2015-Analysis of Death. Bangladesh Politico blog. http://bangl adeshpolitico.blogspot.co.uk/2015/01/political-crisis-2015-analysis-of-deaths.html. Retrieved 24 Feb 2015. 
Bierschenk, T., J. Chauveau, and J.O. de Sardan. 2002. Local Development Brokers in Africa: The Rise of a New Social Category. Working Paper 13, Johannes Gutenberg-Universität.

Blok, A. 1974. The Mafia of a Sicilian Village. Oxford: Basil Blackwell.

Chatterjee, P. 2004. The Politics of the Governed: Reflections on Popular Politics in Most of the World. New York: Columbia University Press.

Devine, J. 2002. Ethnography of a Policy Process: A Case Study of Land Redistribution in Bangladesh. Public Administration and Development 22 (5): 403-414.

Gay, R. 1998. Rethinking Clientelism: Demands, Discourses and Practices in Contemporary Brazil. European Review of Latin American and Caribbean Studies 65: 7-24.

Goldstein, D., and E.D. Arias. 2010. Violent Pluralism: Understanding the New Democracies of Latin America. In Violent Democracies in Latin America, ed. D. Goldstein and E.D. Arias, 1-34. Durham: Duke University Press.

Hackenbroch, K., and S. Hossain. 2012. "The Organised Encroachment of the Powerful"-Everyday Practices of Public Space and Water Supply in Dhaka. Bangladesh. Planning Theory and Practice 13 (3): 397-420.

Hansen, T.B., and O. Verkaaik. 2009. On Everyday Mythologies in the City. Critique of Anthropology 29 (1): 5-26.

Hassan, M., and S. Nazneen. 2017. Violence and the Breakdown of the Political Settlement: An Uncertain Future for Bangladesh? Conflict, Security and Development 17 (3): 205-223.

Jackman, D. 2018. The Decline of Gangsters and the Politicization of Violence in Urban Bangladesh. Development and Change.

Johnson, H.N. 2005. Incivility: The Politics of 'People on the Margins' in Jamaica". Political Studies 53: 579-597.

Khan, M.I.A. 2000. Struggle for Survival: Networks and Relationships in a Bangladesh Slum. PhD thesis, University of Bath, Bath, UK.

Khan, M.H. 2010. Political Settlements and the Governance of Growth-Enhancing Institutions. SOAS Working Paper.

Khan, M.H. 2013. Bangladesh: Economic Growth in a Vulnerable Limited Access Order. In In the Shadow of Violence: Politics, Economics and the Problems of Development, ed. D. North, J. Wallis, S. Webb, and B. Weingast, 1-69. Cambridge: Cambridge University Press.

LeBas, A. 2013. Violence and Urban Order in Nairobi, Kenya and Lagos, Nigeria. Studies in Comparative International Development 48 (3): 240-262.

Martin, N., and L. Michelutti. 2017. Protection Rackets and Party Machines: Comparative Ethnographies of "Mafia Raj” in North India. Asian Journal of Social Science 45 (6): 693-723.

Meehan, P., and S. Plonski. 2017. Brokering the Margins: a Review of Concepts and Methods. Working Paper No. 1. SOAS and the University of Bath.

Michelutti, L. 2007. The Vernacularization of Democracy: Political Participation and Popular Politics in North India. Journal of the Royal Anthropological Institute 13: 639-656.

North, D., J. Wallis, and B.R. Weingast. 2009. Violence and Social Orders: A Conceptual Framework for Interpreting Recorded Human History. New York: Cambridge University Press.

Opel, A.E.A. 2000. The Social Content of Labour Markets in Dhaka Slums. Journal of International Development 12 (5): 735-750.

Ribot, J.C., and N.L. Peluso. 2003. A Theory of Access. Rural Ethnography 68 (2): 153-181.

Rodgers, D. 2006. Living in the Shadow of Death: Gangs, Violence and Social Order in Urban Nicaragua, 1996-2002. Journal of Latin American Studies 38 (2): 267-292.

Ruud, A.E. 2014. The Political Bully in Bangladesh. In Patronage as Politics in South Asia, ed. A. Piliavsky, 303-325. Cambridge: Cambridge University Press.

Scott, J.C. 1972. Patron-Client Politics and Political Change in Southeast Asia. The American Political Science Review 66 (1): 91-113.

Stokes, S.C., T. Dunning, M. Nazareno, and V. Brusco. 2013. Brokers, Voters, and Clientelism: The Puzzle of Distributive Politics. New York: Cambridge University Press.

Suykens, B. 2015. The Land that Disappeared: Forceful Occupation, Disputes and the Negotiation of Landlord Power in a Bangladesh Bastee. Development and Change 46 (3): 486-507.

Suykens, B. 2016. Segmentary Opposition, Vertical Integration and the Structure of Political Relations in Bangladesh: A Descriptive Model. Journal of Asian and African Studies 52 (8): 1141-1158.

Suykens, B. 2017. The Bangladesh Party-State: A Diachronic Comparative Analysis of Party-Political Regimes. Commonwealth and Comparative Politics 55 (2): 187-213. 
The Daily Star. 2015. Bus Driver Hurt in Karwan Bazar Crude Bomb Blast. http://www.thedailystar.net/ bus-driver-hurt-in-karwan-bazar-crude-bomb-blast-61606. Accessed 10 Dec 2015.

Tilly, C. 2003. The Politics of Collective Violence. Cambridge: Cambridge University Press

Tilly, C., and S. Tarrow. 2007. Contentious Politics. Boulder: Paradigm Publishers.

Volkov, V. 2002. Violent Entrepreneurs: The Use of Force in the Making of Russian Capitalism. New York: Cornell University Press.

Von Lieres, B., and Piper, L (eds.). 2014. Mediated Citizenship: The Informal Politics of Speaking for Citizens in the Global South. Basingstoke: Palgrave Macmillan.

Wheeler, J. 2014. 'Parallel Power' in Rio de Janeiro: Coercive Mediators and the Fragmentation of Citizenship in the Favela. In Mediated Citizenship: The Informal Politics of Speaking for Citizens in the Global South, ed. B. Von Lieres and L. Piper, 72-89. Basingstoke: Palgrave Macmillan.

Wolf, E. 1956. Aspects of Group Relations in a Complex Society: Mexico. American Anthropologist. New Series 58 (6): 1065-1078.

Wood, G. 2003. Staying Secure, Staying Poor: The "Faustian Bargain". World Development 31 (3): $455-471$.

Wood, G. 2010. The Security of Agency: Towards a Sociology of Poverty. Paper Presented at Promoting Social Inclusion in South Asia: Policies, Pitfalls and the Analysis of Welfare/Insecurity Regimes, University of Bath. 